\title{
The Role of Religion in Social Cohesion within the Contemporary Muslim Society in Malaysia: Revisited
}

Mohd Arip Kasmo 1

\author{
Bayu Taufiq Possumah ${ }^{2 *}$
}

Zulkifli Mohamad ${ }^{1}$

Wan Zulkifli Wan Hassan ${ }^{1}$

Nasruddin Yunos ${ }^{1}$

${ }^{1}$ Centre For General Studies, The National University of Malaysia, Malaysia

${ }^{2}$ The Institute of Islam Hadhari, The National University of Malaysia, Malaysia

*Corresponding Author Email: aburhamdiusman@yahoo.com

Doi:10.5901/mjss.2015.v6n1s1p168

\begin{abstract}
This study reports the findings of a research involving 400 respondents from all over the country to investigate the effect of industrialisation, modernisation and urbanisation to social cohesion of the Muslim society in Malaysia. The respondents were drawn from all segments of the society, male and female from the age of 16 to 60 years old. Every respondent was given a booklet of questionnaire with statements to be responded. Each statement was provided with five choices of responses ranging from 1. Strongly agree, 2. Agree, 3. Not sure, 4. Disagree, and 5. Strongly disagree. The questions were related to social issues including the issues of social cohesion such as the relations with the neighbours. The relationship with neighbour is an indicator of the social cohesion. The respondent was given 30 minutes to respond to the questionnaire, and the booklets were collected to be analysed using the SPSS. The findings show that social cohesion within the contemporary society changes with urbanisation since the finding show that social cohesion stronger in villages where modernisation and urbanisation effect is not strong compared to those who live in towns and big cities. The finding has also shown that there was a significant difference between the rural social cohesion and the urban social cohesion.
\end{abstract}

Keywords: Religion, Social cohesion, Muslim society, Malaysia

\section{Introduction}

Malaysia is undergoing a rapid economic development, modernisation and urbanisation moving from basically an agricultural country into industrial one, and by 2020 it is projected by the Vision 2020, to become a developed nation (Sarji, 1993). The development process transformed the socio-economy of the country, leading to various changes in the country including the social, political and economic landscape. The economic development has also transformed some segment of the society into an individualistic society where people are more preoccupied with competitions to fulfil the need of modern and industrial society and they slowly become detached from each other. The Muslim community, however could still maintains the cohesiveness of the society through the implementation of the Islamic teachings known as the fard kifayah (communally obligatory) which is collective responsibilities as a group of Muslim (Esposito, 2000), such as performing the daily congregational daily prayers which have to be perform in group in a given locality where at least few individuals member of the society should perform, the compulsory Friday prayer, the congregational night prayers during the fasting month of Ramadan, etc. which provide the mechanisms for social cohesion. Therefore, in the Islamic social system, social cohesion is forged by the teachings of the religion itself and and therefore the stronger the people are attached to the religion, the stronger the social cohesion is. The statements which were proposed to the respondents were related to the social cohesion. At the backdrop of these issues, a study is made to know whether there is a strong correlation between social cohesiveness and the Islamic practices within a society. One of the importance indicators of Islamic practice in a Muslim society is the collective daily prayer attendance. The study tried to find out how strong was the social cohesion among the Muslim society in Malaysia and to see if there was any correlation between the 
strength of the social cohesion and the religious activities of the respondents. The findings of the study can be used by the appropriate authority to map their planning to improve the social cohesion among the Muslim community in Malaysia.

\section{Social Cohesion, What is?}

Social cohesion is defined as the bonds that bind the people together in a society (Hart, et al., 2013). Social cohesion in a society could be weakened by various factors leading into social disintegration. There are many factors which lead to social disintegration, among which is the process of individualisation. Individualisation is a process where an individual becomes detached from the society, to live alone or separated from the rest of the people in the community. The modern and industrial society is base on capitalism and free market system where competition and self interest is at peak. Durkheim (2006) the $17^{\text {th }}$ century French sociologist pointed out the the modern and industrial society would lose the norm and end up in suicide because of the individualism and egoism driven by the endless pursuit of material wealth. The modern and industrial society is based on capitalism and free market system where the economy revolves between production and consumption (Ross, 1991). Workers are encouraged to produce more for higher productivity and the consumers are encouraged to use more. In order for consumption to be increased, the people are encouraged to buy and consumed products by various advertisements for products. In the urban areas where the material need are far more greater than the rural areas, people are more busy and spent more time at the work place than their compatriot in the rural areas. Therefore people in the town and city spend less time with the member of society where they live, and even less time with their spouses and children as expounded by Bauman (2013).

Social cohesion as emphasised by Carron \& Brawley (2000) is the tendency for a group to be in unity while working towards a goal or to satisfy the emotional needs of its members. This definition includes important aspects of cohesiveness, including its multidimensionality, dynamic nature, instrumental basis, and emotional dimension. Social cohesion is in contrast with individualism which is in turn defined the pursuit of individual interest rather than common or collective interest (Wood,1972). Individualism is also defined as the way people give priority to personal goals rather than the common or collective goal (Pillemer, 1998). The transformation of a society into a modern and urban society affected the way the people interact with the society they live in. Urbanization produce a social order in which the traditional ties of communities such as shared space, close kinship links, shared religious and moral values were being replaced by anonymity, individualism and competition (Kearns \& Forrest, 2000). Fukuyama (2000), said that social cohesion was forged because of the common need for safety. Once that needs are fulfilled with other means, social cohesion start to be weakened. Social cohesion between the different ethnic has been a major issue studied and discussed by the sociologists in Malaysia, among which is by Baharuddin (2014) however social cohesion within the ethnic itself has not been studied. Thus this study is an attempt to understand the social cohesion within the Muslim community, focusing the very basic aspect of social cohesion i.e. the level of interaction between the individual within the society and this include the acquaintance with the neighbors. The level of interaction as well as the level of the acquaintance is compared with the basic Islamic teaching of the congregational prayer. Does congregational prayers enhances interaction and the level of the acquaintance with each other.

\section{Social Cohesiveness and the Islamic Practices: An Analytical Measurement}

The study was carried out throughout Malaysia, a sample of 400 respondents were obtained randomly from all over the country. The respondent's ages ranges from 16 years old to 60 years old, male and female. Each respondent was given a booklet containing questionnaire. The questionnaire was in the form of a given statements with five choices of responses, known as Likert Scale ranging from 1 (strongly disagree), 2 (disagree), 3 (not sure), 4 (agree), 5 (strongly agree). According to Domino and Domino (2006), Likert Scale is used to construct attitude scale and hence can be used in this study. The respondents were give 30 minutes to respond to the questionnaire and at the end of the session, the booklets were collected. The data obtained were analysed using the SPSS software. The analysis was to obtained the descriptive including the percentages, means, difference of means etc and the results were presented in the form of table, graphs, diagram, mean, significant difference. The statements are related to social cohesion in a society, namely: 1. I know many of my neighbours, 2. I interact with my neighbours, and 3. I always attend the congregational prayers in the mosque.

In this case, the responses of the first statement "I interacted with my neighbour" and the second one "I know my neighbour" were analysed. The statements are an indicator whether the respondents were socializing with the neighbours or not. The following tables 1 and 2 show the result of the analysis. 
Table 1: The percentage of responses for the statement "I interact with my neighbour"

\begin{tabular}{lcccc}
\hline & Frequency & Percent & Valid Percent & Cumulative Percent \\
\hline Strongly disagree & 2 & .5 & .5 & .8 \\
Disagree & 21 & 5.3 & 5.3 & 6.0 \\
Not sure & 94 & 23.5 & 23.5 & 29.5 \\
Agree & 199 & 49.8 & 49.8 & 79.3 \\
Strongly agree & 83 & 20.8 & 20.8 & 100.0 \\
\hline Total & 400 & 100.0 & 100.0 & \\
\hline
\end{tabular}

Table 1 shows that the percentage of the respondents who strongly disagree with the statement is $0.5 \%$, those who disagree is $5.3 \%$, those who are not sure is $23.5 \%$, those who agree is $49.8 \%$ and those who are strongly agree is 20.8 $\%$. Based on this, those who rejected the statement is $5.8 \%$, those who were not sure is $23.5 \%$ and those who accepted the statement is $79.6 \%$.

Table 2: Response to statement "I know my neighbour"

\begin{tabular}{lcccc}
\hline & Frequency & Percent & Valid Percent & Cumulative Percent \\
\hline Strongly disagree & 5 & 1.3 & 1.3 & 1.3 \\
Disagree & 22 & 5.5 & 5.5 & 6.8 \\
Not sure & 79 & 19.8 & 19.8 & 26.5 \\
Agree & 172 & 43.0 & 43.0 & 69.5 \\
Strongly agree & 122 & 30.5 & 30.5 & 100.0 \\
\hline Total & 400 & 100.0 & 100.0 & \\
\hline
\end{tabular}

Table 2 shows that the percentage of the respondents who strongly disagree with the statement was $0.5 \%$, disagree 5.5 $\%$, not sure $19.8 \%$, agree $49.8 \%$ and those who strongly with the statement was $20.8 \%$. Base on this statistics, the percentage of the respondent who did not accept the statement was $5.8 \%$, and those who were not sure was $23.5 \%$. The percentage of the respondent who accepted the statement was $70.6 \%$. To be clearer, the percentages of the responses were plotted into the percentage curve graph as shown in the Diagram 1.

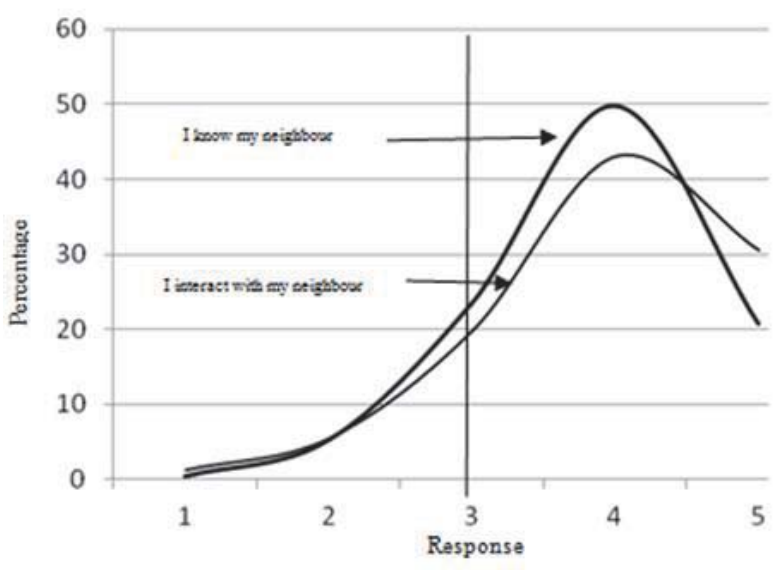

Diagram 1. Percentage responses curve

Diagram 1 shows that the responses are negatively skewed, implying that most of the respondents accepted the statement "I interact with my neighbours". The diagram shows that the curve for the response of the statement "I know my neighbour" is slightly higher than the response for the statement "I interact with my neighbour". This may indicates that people might know each other but they do not interact with each other. The data was then analysed to find the percentages of responses based on the location of the respondents' dwelling. Moreover, the analysis was conducted to find if there are similar trend of responses between the respondents from different location of their dwelling. The result is shown in the following tables. 
Table 3. Percentages of responses according to the location of the dwellings

\begin{tabular}{lcccccccc}
\hline & \multicolumn{2}{c}{ Village } & \multicolumn{2}{c}{ Small town } & \multicolumn{2}{c}{ Town } & \multicolumn{3}{c}{ City } \\
\hline Strongly disagree & 0 & 0 & 0 & 0 & 2 & 1.3 & 0 & 0 \\
Disagree & 4 & 2.6 & 2 & 3.0 & 13 & 8.3 & 2 & 1.3 \\
Not sure & 16 & 10.3 & 18 & 27.3 & 53 & 33.8 & 4 & 25.0 \\
Agree & 87 & 55.8 & 31 & 47.0 & 72 & 45.9 & 8 & 50.0 \\
Strongly agree & 49 & 31.4 & 15 & 22.7 & 17 & 10.8 & 1 & 6.3 \\
\hline Total & 156 & 100 & 66 & 100 & 157 & 100 & 16 & 100 \\
\hline
\end{tabular}

Table 3 shows the percentages of responses according to the location of the dwellings. The pattern of the responses is not clear until the percentages of the responses were plotted into the curves graph as shown in the following diagram.

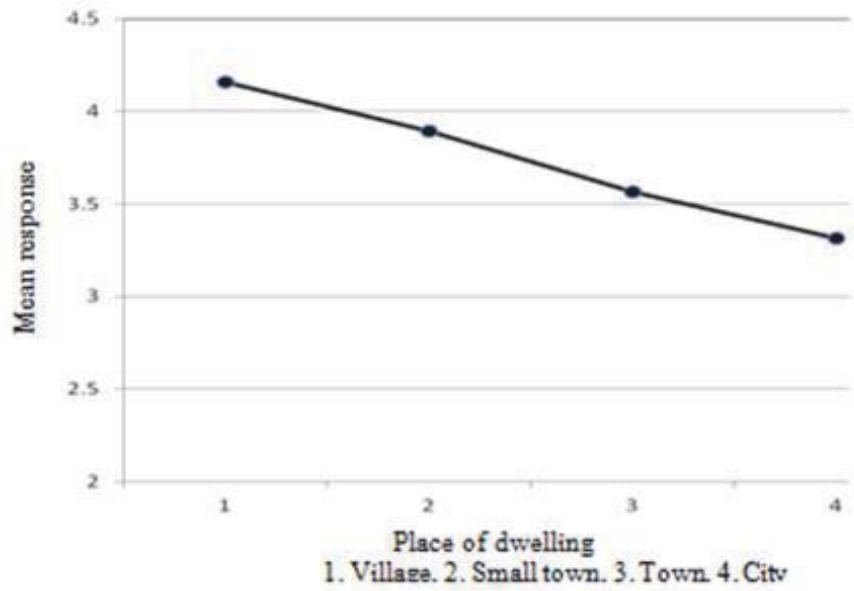

Diagram 2. Mean responses for the statement "I know my neighbour" according to place of dwelling

Diagram 2 shows line graph showing the means response according to the place of dwelling. The means response gradually decreases from 1 (village dwelling) to 2 (small town), to 3 (town) to 4 (city). The line graph shows that the extent of acquaintance with the neighbour decreases with the localities of the dwelling with the strongest for the villages dwellers and the least with the city dwellers.

Table 4. The mean responses according the location of the dwelling

\begin{tabular}{lccc}
\hline Place of dwelling & Mean & $\mathrm{N}$ & Std. Deviation \\
\hline village & 4.1603 & 156 & .70479 \\
Small town & 3.8939 & 66 & .78699 \\
town & 3.5669 & 157 & .84181 \\
City & 3.3125 & 16 & 1.19548 \\
\hline
\end{tabular}

Table 4 shows the results of the analysis of mean for the responses according to the location of the dwelling of the respondents. The highest acceptance of the statements "I interact with my neighbours" is those from the villages, followed by the responses from those who live in small town, town and city.

Similarly the analysis of mean for the respondents to the statement "I know many of my neighbours", show similar trend except very small difference between the mean response for the respondents who live in town and city, and the following table shows the mean. 
Table 5. The mean response to the statement "I know many of my neighbours"

\begin{tabular}{lccc}
\hline Place of dwelling & Mean & $\mathrm{N}$ & Std. Deviation \\
\hline Village & 4.3526 & 156 & .72561 \\
Small time & 4.0303 & 66 & .74358 \\
Town & 3.5796 & 157 & .96826 \\
City & 3.6250 & 16 & 1.02470 \\
\hline
\end{tabular}

Table 5 shows the means responses according to the location, showing the highest mean is the mean for the respondents who live in the villages, followed by the respondents who lived in the small town, the city and town. T-test was used to see if the difference of mean are significant or not. The following table shows the t-test value between the responses of the respondents who dwell in the village and the small town. The following table shows the $p$ values for the difference of means between the respondent who live in villages and those who live in small town.

Another statement which is very strongly related to the social cohesion is the attendance of the daily congregational prayer at the local mosque. The statement "I always attend the daily congregational prayer at the local mosque". The mean responses according to the location of the dwelling is shown in the following table.

Table 6. The mean response for the statement "I always attend the Congregational daily prayer at the local mosque"

\begin{tabular}{lccc}
\hline Location of dwelling & Mean & $\mathrm{N}$ & Std. Deviation \\
\hline Village & 4.0256 & 156 & 3.33689 \\
Small town & 3.2121 & 66 & 1.50400 \\
Town & 3.1783 & 157 & 1.63497 \\
City & 2.8125 & 16 & 1.79699 \\
\hline
\end{tabular}

Table 6 shows that the mean response for the statement "I always attend the congregational daily prayers at the local mosques" is the highest for the respondents who dwell in the villages (4.0256), followed by the respondents who dwell in the small town (3.2121), and the respondents who dwell in the town (3.1783) and the smallest is those who dwell in the city (2.8125). The means responses are then shown in the form of means curves graph as shown in the following diagram.

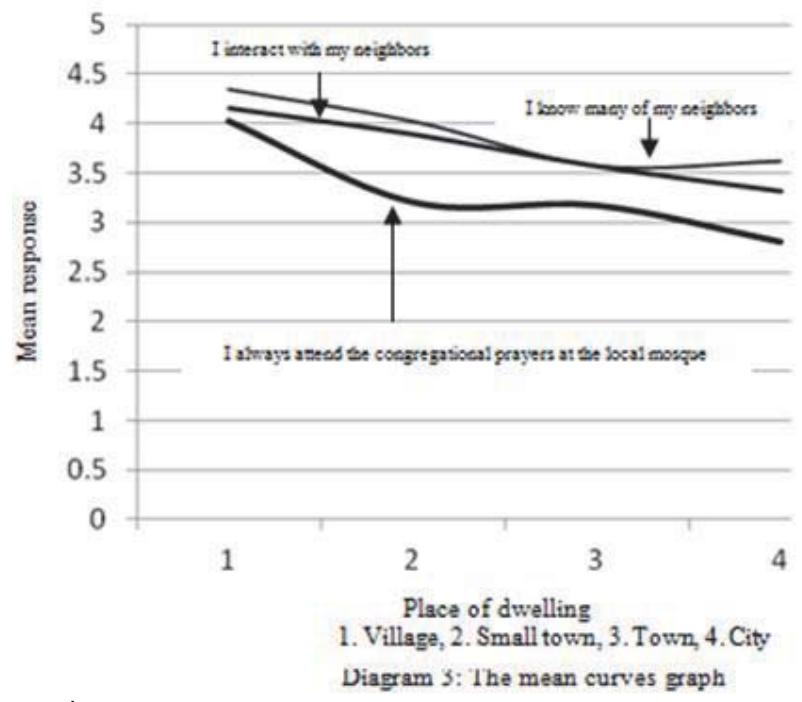

Diagram 3: The mean curves graph

Diagram 3 shows that the mean response for the statements, namely: 1. I interact with my neighbour, 2. I know many of my neighbours, and 3. I always attend the congregational daily prayer at the local mosques, progressively become smaller (the rejection of the statement) from the highest (acceptance of the statement).

\subsection{Correlation test}

The correlation test between the mean responses for the three statements was made to know whether there are correlation between the means responses to the three statements and the result are shown in the following table. 
Table 7. Correlation between the responses of the three statements

\begin{tabular}{|c|c|c|c|c|}
\hline & & Know neighbour & Collective praye & interact \\
\hline \multirow{3}{*}{ Know many of my neighbour } & Pearson Correlation & 1 & $.110^{*}$ & $.461^{* *}$ \\
\hline & Sig. (2-tailed) & & .028 & .000 \\
\hline & $\mathrm{N}$ & 400 & 400 & 400 \\
\hline \multirow{3}{*}{ Collective daily prayer } & Pearson Correlation & $.110^{*}$ & 1 & $.191^{\star *}$ \\
\hline & Sig. (2-tailed) & .028 & & .000 \\
\hline & $\mathrm{N}$ & 400 & 400 & 400 \\
\hline \multirow{3}{*}{ Interact with the neighbour } & Pearson Correlation & $.461^{* *}$ & $.191^{* *}$ & 1 \\
\hline & Sig. (2-tailed) & .000 & .000 & \\
\hline & $\mathrm{N}$ & 400 & 400 & 400 \\
\hline
\end{tabular}

Table 7 shows that there are strong correlation between the mean responses for the three statements. The results show that there are strong correlation between collective daily prayers, knowing ones neighbours as well as interaction with one neighbours.

\subsection{T-Test}

The t-test was conducted to know whether the difference of mean is significant. The following tables show the result of the analysis.

Table 8. The p-values between the mean response of the respondents who live in villages and small town.

\begin{tabular}{lccccc} 
& $\mathrm{F}$ & Sig. & $\mathrm{t}$ & $\mathrm{df}$ & Sig. (2-tailed) \\
\hline Equal variances assumed & 1.146 & .286 & 2.484 & 220 & .014 \\
\hline Equal variances not assumed & & & 2.376 & 111.225 & .019 \\
\hline
\end{tabular}

Table 8 shows that the p-value 0.014 is smaller than the critical value of 0.05 , indicating that the difference of mean between the responses of the respondents' village and the small town is significant.

Table 9: The t-test between the village and town

\begin{tabular}{lccccc}
\hline & $\mathrm{F}$ & Sig. & $\mathrm{T}$ & $\mathrm{df}$ & Sig. (2-tailed) \\
\hline Equal variances assumed & 12.046 & .001 & 6.759 & 311 & .000 \\
\hline Equal variances not assumed & & & 6.763 & 302.315 & .000 \\
\hline
\end{tabular}

Table 9 shows that there is a significant difference of means between the mean response of the respondents who dwell in the village and those live in town is significant.

Table 10. T-test between town and city

\begin{tabular}{lccccc}
\hline & $\mathrm{F}$ & Sig. & $\mathrm{T}$ & $\mathrm{df}$ & Sig. (2-tailed) \\
\hline Equal variances assumed & 2.235 & .137 & 1.103 & 171 & .271 \\
\hline Equal variances not assumed & & & .830 & 16.550 & .418 \\
\hline
\end{tabular}

Table 10 shows that there was no significant difference between the mean responses of the respondent who dwell in the town and city. The difference of mean between the mean response of the respondents who live in town and the respondents who live in city is not significant.

\section{Finding and Discussion}

The findings of the study show $5.8 \%$ of the respondents did not interact with their neighbours. Majority of the respondents claimed that they knew many of their neighbours and they interacted with their neighbours. However, when 
the data was analysed to see the profile of the responses base on the localities of the dwellings, i.e. the villages, the small towns, town and cities, the pictures become clearer that the people living in towns and cities are more individualistic, meaning that they have less interaction with each other and less acquaintance with each other's, than those who live in the villages. This can be seen from the means responses which show that the mean is greatest for the respondents who live in the villages and smallest for the respondents who live in towns and cities. The t-test which was conducted to see if the difference of mean is significant indicates that the difference of mean between the villages and small town is significant, the mean difference between the village and the town is also significant, and the difference of mean between the villages and cities is also significant. One of the indicators which show that individualism gradually getting stronger from villages to city could be seen from the response to the statement "I attend the congregational daily prayer at the local mosque". The means responses as shown in table 5, show that the responses is greatest for the respondent who lived in villages. The greatest mean responses that the respondents accept the statement while it is smallest for the responses of the respondent who live in city. The response is an indicator that the people in the town and city are more dissociated with each others compared to those who live in villages.

Then t-test results show that there is significant different between the mean response for the respondents who live in the village and the rest of other places. There was significant difference between the respondent who live in town and city. There are many reasons which lead to the difference. Within the Muslim society in Malaysia, village is a close knitted society in which people know each other through various activities which are related to the religious teachings such as the daily congregational prayers, the weekly Friday prayer, the annual festive prayers, the compulsory collective prayer and burial for dead person. Besides that, people in the village are bonded together with the social activity known as gotong royong (mutual help) where the people work together to do common interest works such as cleaning the mosques, the burial ground or even the preparation for wedding (Nakamura, 2001). The gotong royong is underpinned by the Islamic concept of ummah where each Muslim is responsible for fellow Muslim (Mellahi \& Wood, 2004). These activities are slowly neglected when a person dwell in the town or city. This is the reason why the people who live in town and city are more dissociated with each other than those who live in villages. The factors have been indirectly by the theory postulated by Durkheim (2006) in which he said that people living in modern and industrial society tend to be more individualistic and egoistic. The people living in a modern and industrial society tend to be preoccupied with fulfilling the material needs. More time is spent at the working places such as in the offices, business premises for more income while those living in the villages which are basically rural in nature.

\section{References}

Baharuddin, S. A. (2014). Unity, Cohesion, Reconciliation : One Country, Three Cherished Concepts. Bangi: The National University of Malaysia.

Bauman, Z. (2013). The individualized society. Cambridge: Polity Press.

Carron, A.V. \& Brawley, L. R. (2000). Cohesion: Conceptual and Measurement Issues. Journal of Small Group Research, February 2000, vol. 31, no. 1, pp. 89-106. DOl: 10.1177/104649640003100105.

Domino, G. \& Domino, M. L. (2006). Psychological Testing: An Introduction. Cambridge, UK: Cambridge University Press.

Durkheim, E. (2006). Suicide: A Study In Sociology. United Kingdom: Penguin Classics.

Esposito, J. L. (2000). The Oxford History of Islam. Oxford University Press.

Fukuyama, F. (2000). The Great Disruption: Human Nature and The Reconstitution of Social Order. New York: Touchstone.

Hart, J. D. et.al. (2013). Religion and Civil Society in Europe. London: Springer Science \& Business Media.

Kearns, A. \& Forrest, R. (2000). Social Cohesion and Multilevel Urban Governance. Journal of Urban Studies, vol. 37, no. 5-6, pp. 9951017. DOI: $10.1080 / 00420980050011208$.

Mellahi, K. \& Wood, G. (2004). HRM in Malaysia. In Pawan S. Budhwar. (Ed.) Managing Human Resources in Asia-Pacific. United Kingdom: Routledge, pp. 201-220

Nakamura, M. (2001). Islam and Civil Society in Southeast Asia. Singapore: Institute of Southeast Asian Studies.

Pillemer, D. B. (1998). Momentous Events, Vivid Memories. Cambridge: Harvard University Press.

Ross, P. (1991). Morality and Modernity. Rutledge: New York.

Sarji, A. (1993). Malaysia's vision 2020: Understanding the concept, implications and challenges. Petaling Jaya: Pelanduk Publication.

Wood, E. M. (1972). Mind and Politics: An Approach to the Meaning of Liberal and Socialist Individualism. Berkeley: University of California Press. 